\title{
A explosão da flor: o exercício poético em João Cabral de Melo Neto
}

\author{
The explosion of the flower: poetic exercise in João Cabral de Melo Neto's poetry
}

\author{
GLÓRIA ALHINHO \\ Université Bordeaux Montaigne. Pessac, França.
}

$-7$

Resumo: O poema “A Lição de Poesia” da coletânea O Engenheiro, anuncia o relevo da matéria em vários níveis da poesia de João Cabral de Melo Neto. O poeta não cessará de lhe extrair densidade e profundidade para produzir uma poesia depurada na qual se confrontam os desejos de clareza e de surpresa sempre assentes na concretude do mundo físico. A partir da matériatanto da dimensão física como da transformação pelo trabalho artístico (pelo gesto, pela pintura, pela escrita, pela arquitetura, pelo canto, pela tauromaquia...) -, este poeta faber aproxima a poesia do mundo das coisas e da sua raiz, a emoção, fazendo, porém, explodir a sua natureza e arriscando caminhos até e para além da lírica flor.

Palavras-chave: João Cabral de Melo Neto; Trabalho poético; Poeta faber; Criação artística; Literatura brasileira.

\begin{abstract}
A Lição de Poesia", in O Engenheiro, underlines the importance of matter as a means of understanding different levels of João Cabral de Melo Neto's poetry. The poet adopts a distance towards romantic and lyrical tradition and works, instead, with the density and depth of material things. Nevertheless, his poetry incorporates forms from older poetic traditions such as Iberian literature and popular Brazilian poetry. In that sense, the poet considers that the search for emotion is still worthwhile, but he tries to attain it in a different way. Indeed, the aesthetic dimension of other artistic worlds is also a precious lesson for this poeta faber who discovered that the purest roots of poetry may also be found in the gestures of a painter, bullfighter, architect or singer.
\end{abstract}

Keywords: João Cabral de Melo Neto; Work on poetry; Poet faber; Artistic work; Brazilian literature.

"//E as vinte palavras recolhidas/ nas águas salgadas do poetal e de que servirá o poeta/ em sua máquina útil.// Vinte palavras sempre as mesmas/de que conhece o funcionamento, / a evaporação, a densidade/ menor que a do ar./P"

"A Lição de Poesia" in $O$ Engenheiro. JoÃo CABRAL DE MELo Neto 
De tudo aquilo que João Cabral de Melo Neto disse sobre a sua criação poética permanece a ideia, muito precisa, de que uma maçã interessa-o mais do que a tristeza. Não podemos, porém, considerar a maçã destituída de qualquer emoção pois cada objecto ou matéria deveria mostrar o estado de espírito do poeta $^{1}$, segundo afirma. Ortega y Gasset tece algumas considerações sobre a profundidade e interioridade dos objetos que nos podem ajudar a compreender o exercício poético onde a maçã como matéria se sobrepõe à tristeza como abstração. A partir do exemplo de uma laranja, Ortega y Gasset afirma que a claridade daquilo que está à superfície não pode definir a sua interioridade e por mais que as decompuséssemos em finas camadas, nunca essa transparência poderia definir o que possui (1932: 22). Haverá, portanto, sempre algo de inacessível e inatingível em qualquer matéria e talvez seja a vontade de transformar a sua opacidade e objetividade "em matéria estética, sensível e transparente.", segundo nos sugere Carlos Vidal (NUNES, 2016, p. 21), que anima a criação estética, seja ela de que natureza for.

Esta reflexão pode elucidar-nos sobre a espessura e a densidade que caracterizam a matéria na poesia de João Cabral de Melo Neto, chegando esta última mesmo a defini-la² (ALMINO 2000, p. 127). Dessa matéria densa, compacta e espessa, o poeta parece ter tirado várias lições, sobretudo a da pedra, como sugere Arnaldo Saraiva (2014, p. 33). De facto, a introdução de pedra e facas num universo para o qual nos remete lição, composição, educação e escola nos títulos das suas publicações ${ }^{3}$, sugere a relevante dimensão didática da matéria antes de ser poesia. Esses elementos, aparentemente dissonantes, resistem à observação imediata que temos dos exercícios de compor, de educar e de leccionar, obrigando o leitor a aventurar-se num novo campo de possibilidades semânticas. Diríamos que a introdução destes objetos deforma as primeiras imagens ${ }^{4}$ de ambos os universos pedagógico e poético - e anuncia a experiência singular da aprendizagem que atravessa toda a obra cabralina, quer ligada ao trabalho da linguagem, quer à génese e ao funcionamento da poesia.

\footnotetext{
Tal como diz em entrevista a António Carlos Secchin: "O poeta deveria demonstrar seu estado de espírito até no ato de descrever o açucareiro.' (1985, p. 305).

2 Veja-se, por exemplo, as últimas estrofes de O Cão sem Plumas (19491950)

3 As publicações que surgem a seguir a O Engenheiro (1942-1945), do qual faz parte Lição de Poesia, e que são, respetivamente, Psicologia da Composição (1946-1947), A Educação pela Pedra (1962-1965) e $A$ Escola das Facas (1975-1980). Repare-se que este universo, para que remete lição, está presente ao longo da obra.

4 Remetemos o leitor para a análise que Gonçalo M. Tavares faz do pensamento de Gaston Bachelard obre a imaginação em L'air et les songes publicado em 1943 (Tavares, 2013, p. 377)
}

O exercício ${ }^{5}$ poético tem uma dimensão dinâmica e é dele que nasce a interrogação permanente sobre a densidade da realidade e da sua materialidade. Este movimento provoca uma tensão ${ }^{6}$ entre aquilo que a poesia é e aquilo que ela também poderá ser. Estas confrontações surgem na encruzilhada de aproximações e afastamentos em direção à origem da poesia e da sua relação com a matéria. Nela se encontra o desejo da expansão de si mesmo (até às suas águas salgadas) e da explosão daquela que parece encerrar todos os mistérios: a flor cabralina.

João Cabral de Melo Neto conduz um trabalho crítico sobre a linguagem e sobre a poesia que se apoia no desejo de apreender e compreender a palavra poética. Para tal, situa-a no plano da concretude e no esvaziamento de tudo o que possa comprometer o trabalho de observação do real. Deste modo, procura-se, numa primeira fase, indagar se a origem desta poesia se situa no plano da realidade tangível antes que se traduza em linguagem poética e em ensino do que ela é. O essencial para se encetar um caminho para a origem da poesia situa-se pois tanto no plano dos objetos - na realidade física - como no corpo humano - na precisão da gestualidade - até à paisagem na aridez e despojo.

Por esta razão, numa segunda fase, analisa-se o desejo de apreensão da realidade pois nele existe a função pedagógica explícita de ensinar a fazer a poesia. O ensino do seu funcionamento pressupõe um trabalho de análise da linguagem e da procura de precisão como método de estudo para chegar a outras dimensões daquilo que foi e é a poesia. O permanente diálogo com outras obras e outros criadores, sustenta este método num exercício a que se chamou a sua poesia crítica. Em suma, este trabalho da aprendizagem é essencial para qualquer forma de criação pois o criador é aquele que trabalha a aprendizagem.

Restará, numa terceira fase, analisar os resultados da materialização da escrita, pois ela revela outras origens. A máquina e o trabalho de precisão eram apenas instrumentos de acesso à dimensão mais intangível da matéria. A sua transformação numa máquina útil pode levar o poeta até à explosão daquilo que já conhecia à partida. O desafio está, então, na maneira como o poema pode dar a ver a profundidade e a interioridade da matéria seja ela a da maçã, da lama ou da flor. É, contudo, para esta última que parecem convergir vários caminhos que o sujeito lírico experimenta para chegar até à sua origem e à da sua flor.

\footnotetext{
Numa carta enviada a João Cabral de Melo Neto, Manuel Bandeira diz que tinha uma ideia da sua poesia como sendo "uma espécie de exercício, mas exercício que não excluía a categoria altamente poética." (SÜSSEKIND, 2001, p.126)

6 Como disse Maria Andresen de Sousa Tavares: "Qualquer definição afirmativa desta poesia requer um mas que, se não a denega, pelo menos faz emergir uma tensão." (2001, p. 227).
} 


\section{Procurando as origens da matéria e da poesia}

De acordo com os traços gerais apontados pela crítica, $O$ engenheiro caracteriza-se tanto pelo desprendimento a temáticas anteriores (o sonho e o sono) como a um ensaio da forma, ou seja, uma "consciência poética" que implica superar o espaço onírico para investir na linguagem do concreto (SECCHIN, 2014, p. 39). O processo de afastamento começa mesmo antes, em $O s$ Três Mal-Amados, no desejo de libertação de tudo o que constitui um saber livresco associado a um certo corpus poético7: "//Joaquim:/ O amor comeu na estante os meus livros de poesia. Comeu em meus livros de prosa as citações em verso. Comeu no dicionário as palavras que poderiam se juntar em versos.//" (MELO NETO, 2003, p. 59). É reconhecida a vontade de destruir o saber livresco e poético ao qual está sujeito o uso da palavra amor. Pretende-se, pelo contrário, que este advenha da sua consciência como matéria - daí o amor até devorar a própria identidade tanto do sujeito lírico como do próprio poeta. Aqui se adivinha o desejo de transformar o poema numa "máquina útil" onde seja possível textualizar e controlar essa matéria sem ser condicionado pela figura indomável de um universo amoroso de contornos românticos.

Compreende-se, assim, que em $O$ engenheiro a matéria física que serve para fazer o poema: a tinta, o lápis, o papel, o carvão - evocados nos poemas "O Poema" e "Lição de poesia" - seja uma possibilidade de fazer brotar esse ser vivo que é o verso: "// Como ser vivo/ que é um verso,/ um organismo// com sangue e sopro,/ pode brotar/ de germes mortos?//" (MELO NETO, 2003, p. 76). Contudo, por ser esse organismo de sangue $e$ de sopro, o poeta sabe que tem que lutar - embora se trate de uma luta branca, ou seja, uma luta literária, pois é ela que gera os monstros - contra bichos, fantasmas, para conseguir controlar a criação poética. Deste modo, é na caracterização física mesmo da matéria poética (que pode circular, urinar e sujar o papel na qual escreve que o poeta) vai poder encontrar as suas veias de água salgada $\mathrm{e}$ recolher apenas as vinte palavras de que necessita ${ }^{8}$.

É com O Engenheiro, em 1945, que João Cabral "enceta a fase definitiva da sua obra" (apud BARBOSA, 1972, p.94) pois é desactivada a dimensão onírica e retirada a aura à palavra para que ela possa ser trabalhada como "figura da linguagem" (SECCHIN 2014, p. 39). De facto, "A Lição de Poesia" cria um universo temático à

\footnotetext{
7 Marta de Senna sugere que Os Três Mal-Amados possa representar as diferentes relações que João Cabral de Melo Neto mantém com a poesia (SENNA, 1980, p. 13).

8 As palavras destacadas a itálico são extraídas do universo temático do poema "A Lição de Poesia".

9 João Alexandre Barbosa atribui esta afirmação a Haroldo de Campos.
}

volta de palavras, poeta e máquina que elucida alguns dos novos caminhos da poesia de João Cabral de Melo Neto. O poeta trabalha a partir da matéria-prima que são as vinte palavras, repetidas e aprendidas, para que estas ponham a funcionar essa máquina na qual se pode tornar o poema. Aqui encontramos explícita a afirmação de João Alexandre Barbosa sobre a relação indissociável entre o fazer e o dizer da poética cabralina (1972, p.93). Existe, ainda, um outro nível de exercício sobre a matéria à qual o poeta aspira pois ele reconhece que sabe ofuncionamento, a evaporação e a densidade das suas palavras salgadas mas que tem um menor conhecimento do ar, ou seja de outra dimensão para ou na qual elas podem evoluir. Aqui se confrontam vários níveis de significação da palavra e do exercício poético, à qual ela está sujeita, para se atingir a concretude do mundo físico. Daí João Cabral de Melo Neto ter dito que "o objeto toca você por todos os sentidos. O abstrato, não." (CASTELLO, 1996, p. 62). Assiste-se, com efeito, a um trabalho de presentificação da expressão através da palavra mais do que representação, como esclarece João Alexandre Barbosa $\left(1972\right.$, p. 99) ${ }^{10}$. No entanto, só por si, este trabalho revela-se insuficiente e adivinha-se uma atenção permanente à parte mais secreta e intangível da poesia. Existe um desejo de utilizar a máquina útil na qual se pode transformar o poema - ou a maneira de fazer o poema ou mesmo o objecto ou o corpo da qual se forma ou que explica o poema - para compreender o ato criativo e a origem da poesia ${ }^{11}$.

Mais uma vez - como no caso do amor em Os Três Mal Amados -, o acesso à criação textual dá-se através da aprendizagem do que constitui o mundo enquanto matéria pois é este que poderá definir o texto poético e não o inverso ${ }^{12}$. $\mathrm{O}$ desejo de compreender a matéria física (a água, o ar, a evaporação, a densidade) conduz à compreensão do funcionamento das palavras. Neste sentido, as águas salgadas do poeta poderiam ser mesmo o sinónimo das vinte palavras recolhidas. Ambos os universos (o das águas e o das palavras) designariam a expansão tanto do sujeito enquanto criador, através da aprendizagem, como a da matéria pois esta pode também

\footnotetext{
${ }^{10}$ Este trabalho é visível noutros textos. Veja-se, a este propósito, no poema "Rios sem Discurso" de A Educação pela Pedra (1962-65): “/Em situação de poço, a água equivale/a uma palavra em situação dicionária/". Aqui, a palavra "equivale" estabelece uma comparação concreta oriunda de uma linguagem matemática, evitando assim a multiplicação de sentidos para os quais poderia remeter a metáfora poço/dicionário.

11 Veja-se em $O$ Cão sem Plumas como a máquina útil é a própria fruta.

12 Este processo é levado a cabo de uma forma exemplar no poema supra citado: o rio é discurso-rio, a água do poço é apresentada como "uma palavra em situação dicionária"; um encadeamento e imbricação de sentidos estabelece-se entre o curso da água de um rio e a sua sintaxe ou seja, entre o encadeamento de frases que forma um discurso e o encadeamento de poços que forma um fio de água, podendo estes mesmo chegar a se enfrasear (MELO NETO, 2003, p. 350-351). Maria Andersen de Sousa Tavares diz que a intromissão da sintaxe como figura de raciocínio e da análise é um procedimento próprio à poesia de João Cabral de Melo Neto (2001, p. 300).
} 
integrar uma dimensão criativa e de criação - como a das palavras. Assim, o poema "A Lição de poesia" dá-nos conta da importância da experiência de aprendizagem através do exercício, para apreender e aprender a palavra poética. Trata-se de escolher a via apontada, entre outros, por Valéry: a do poeta faber $^{13}$ que envereda por uma poesia consciente que identifica poesia e pensamento ${ }^{14}$. Como esclarece María Zambrano, a poesia deixa de ser um sonho e o poeta passa a falar daquilo que permanecera em silêncio: o seu trabalho (Zambrano, (2003 [1939], p. 114). Veremos que esse desejo de ensinar $a$ é também importante para João Cabral de Melo Neto na sua relação com o trabalho do outro, como refere Marta de $\operatorname{Senna}^{15}$ (1980, p. 1).

Maria Zambrano alerta que neste desejo de exatidão e de lucidez, o sonho não pode ser posto de lado pois ele é a raiz da poesia. Apenas o esforço para a sua expressão passa a estar no plano do consciente (ZAMBRANO, 2003 [1939], p.114). De facto, ao trabalho de precisão e de concretude, apontado pela crítica, dir-se-ia que existe um outro esforço para o saber que mostra uma poesia em permanente movimento e que abre inúmeros caminhos para a compreensão de onde vem, como se a trabalha e para onde ela pode ir. Esta dimensão futurante encontra-se até na forma como ela olha o trabalho do outro e como da sua singularidade surge a raiz da poesia.

\section{Trabalhando a matéria poética}

A produção poética de João Cabral vai revelar, a partir desta fase, um desejo de autocontrolo e de precisão. O objectivo é chegar às coisas e, para tal, procura-se a matéria que as constitui para com elas se trabalhar uma escrita depurada e liberta de todas as armadilhas. Estas armas ou, diríamos, instrumentos de trabalho, podem dissecar a realidade e tirar-lhe o supérfluo. O universo da palavra vai assim cruzar o da pedra, da faca, da bala, da lâmina pois estas contêm uma realidade física palpável que transporta um significado preciso sem transbordar em significações abstractas ${ }^{16}$. A palavra torna-se um instrumento controlável e até mesmo uma figura da linguagem ${ }^{17}$ com um fim bem definido.

\footnotetext{
${ }^{13}$ A designação pertence, neste contexto, a María Zambrano (2003 [1939] ,p. 113).

${ }^{14}$ Ver a este propósito o trabalho de Maria Andresen de Sousa Tavares intitulado, precisamente, Poesia e Pensamento (Tavares, 2001).

${ }^{15}$ Marta de Senna cita um artigo intitulado "A geração de 45 " que surgiu no Diário Carioca em 30 de novembro de 1952, p." "O que o poeta jovem procura nesse poeta mais antigo [Carlos Drummond de Andrade] é uma definição ou uma lição de poesia [...] um conceito de poesia, a partir do qual realizará sua própria poesia." "(SENNA, 1980, p. 1).

${ }^{16}$ Como esclarece o corpus crítico sobre a poesia de João Cabral de Melo Neto: há um desejo de presentificação das coisas tal como elas são mais do que a sua representação.

17 A expressão pertence a Antonio Carlos Secchin (2014, p. 39).
}

Este fim é também aquele que ela transporta como palavra do outro e, por essa razão, nunca se recusa o que ela já oferece pela voz de outros poetas. As primeiras afinidades chegam de uma Geração anterior à sua, a do Movimento de 22, nas figuras de Murilo Mendes, Carlos Drummond de Andrade e Joaquim Cardozo, cujas obras revelam um traço comum: a neutralização do lirismo puro. Serão muitos outros universos artísticos que revelam a admiração pela busca da matéria depurada e liberta de uma carga semântica envolvente que venha comprometer a sua essência como "coisa, coisa", tal como é definido o trabalho de Piet Mondrian no poema "No Centenário de Mondrian". Neste, o sujeito lírico diz travar-se uma luta de "corpo a corpo" para que se possa chegar apenas ao essencial de cada coisa: "/em que umas poucas coisas/ revelem-se, compactas,/ recortadas e todas// e chegar entre as poucas/ à coisa coisa e ao miolo/ dessa coisa, onde fica/ seu esqueleto ou caroço,// (MELO NETO, 2003, p.377). É neste contexto que poderíamos ainda compreender o diálogo permanente na sua obra com figuras relevantes do mundo da arte e com outros campos teóricos, na tentativa daquilo que o poeta designou como sendo a procura da surpresa como estímulo para o fazer. Deste modo, o poeta é como qualquer outro artesão, arquiteto, pintor, escritor. No poema "A Vicente do Rego Monteiro", o sujeito lírico diz não poder reduzir o trabalho daquele ao de um pintor ou de um professor porque estas palavras que designariam a sua profissão, nada dizem das surpresas perante as quais a sua obra o coloca (MELO NETO, 2003, p. 80-81).

São inúmeras as referências a outros escritores e à forma como cada um opera e disseca a linguagem para extrair a matéria com a qual cria, quer seja a clareza, a concisão, o silêncio ou outros procedimentos. Este trabalho faz de si um poeta aprendiz ${ }^{18} \mathrm{e}$ da sua poesia uma escola-oficina onde questiona outras formas de criação artística. Assim, no poema "O Sim Contra o Sim", através da metáfora do instrumento cortante, em que o lápis se transforma, o bisturi, descreve-se a forma como Marianne Moore o usa para criar a economia vocabular, a exatidão ou a agudeza com que chega ao real: "/E porque é limpa a cicatriz,/ econômica, reta,/mais que o cirurgião/se admira a lâmina que opera.//" (MELO NETO, 2003, p.297). Também no poema que dedica a Paul Valéry, intitulado "A Paul Valéry", celebra o equilíbrio perfeito entre $o$ apetite de menos e a tranquilidade do não-fazer como outra matéria de trabalho que pode operar no sentido de transformar a palavra em silêncio. Esta celebração pode levar à impossibilidade do poema mas este é uma das tais surpresas ou

\footnotetext{
18 A expressão é de José Castello (1996).
} 
sustos $^{19}$ que o contato com a palavra do outro pressupõe, ou seja, o risco de ser surpreendido no interior da própria aprendizagem. Desta forma, arriscam-se outros caminhos que possam conduzir o poeta à incerteza dentro da sua própria poesia.

A arquitetura e a engenharia, e especificamente, o arquiteto Le Corbusier vão abrir-lhe horizontes no campo dos atributos físicos dos objetos e da matéria. João Cabral de Melo Neto diz mesmo ter sido mais influenciado por este autor do que por qualquer outro teórico, sobretudo no pensamento que aquele desenvolve em Quand les cathédrales étaient blanches. Com efeito, é uma frase de Le Corbusier que utiliza como epígrafe para $O$ Engenheiro: "Machine à émouvoir ". Só por si, a escolha desta epígrafe já anuncia aquilo que João Carlos Secchim nomeia um paradoxo: tirar a aura às palavras e a carga de ilusionismo mas admitindo-as sempre na esfera do indecifrável. Não se deixa, assim, de fortalecer o aspeto mítico da poesia, na medida em que a idealiza num tempo ou espaço ideais onde ela possa despertar a emoção da surpresa. Contudo, Marta de Senna diz tratar-se apenas de um outro ângulo através do qual a poesia pode ser vista. $\mathrm{O}$ exercício poético exige a mesma clareza que a construção de qualquer objeto técnico mas sem a afastar daquilo que é também a sua raiz: a emoção. Esta deve apenas ser entendida de outro modo (ou chegar-se a ela de outra maneira):

Tal é o propósito do livro: atingir a emoção por via da precisão e não do vago, que a poesia tem por finalidade a emoção, mas deve ser construída com o mesmo rigor com que se constroem os objetos técnicos (SENNA, 1980, p. 6).

Como sugere Arnaldo Saraiva, João Cabral de Melo Neto tira da matéria mais resistente - como a da pedra - uma lição de moral antes de qualquer outra e, ainda, uma lição de uma pedra "muito especial" que é a do Sertão (SARAIVA, 2014, p.33). De facto, no poema "A educação pela pedra", ao longo da primeira estrofe, o sujeito lírico sugere que é preciso frequentar a pedra e aprender tanto a moralidade da sua "resistência fria" como a poética da sua "carnadura concreta". Na segunda estrofe, passa a considerar "Outra educação pela pedra" que apesar de nada ensinar "entranha a alma" (MELO NETO, 2003, p.338). Neste caso, poderíamos dizer que se existe o interesse em ir buscar a palavra precisa

\footnotetext{
19 Por exemplo, na fala de Raimundo em Os Três Mal-Amados, praticar os exercícios (que pressupõem ouvir outras vozes da matéria) pressupõe a certeza do susto nesse caminho para a criação poética: “/(...) susto cuidadosamente oculto, como qualquer animal venenoso entre as folhas claras e organizadas dessa floresta numerada que leva dísticos explicativos: poesia, poemas, versos./" (MELO NETO, 2003: 63).
}

- como, neste caso, a palavra pedra -, existe também a consciência das possibilidades da composição que ela permite ${ }^{20}$.

O caminho é, então, apenas outro porque a partir do momento em que se objectiva a criação poética, deseja-se ultrapassá-la para se atingir outro nível de conhecimento ou possibilidades para a emoção. $\mathrm{O}$ atributo densidade que caracteriza a palavra ainda matéria, evolui para evaporação à qual aquela está sempre sujeita. Sabendo que a depuração das palavras pode conduzir ao seu esvaziamento: "// então, nada mais/ destila; evapora/ onde foi maçã/ resta uma fome;// onde foi palavra/ (potros ou touros/ contidos) resta a severa/ forma do vazio//." (MELO NETO, 2003: 97). Esta evaporação é concretizada efetivamente nas últimas estrofes do poema "Psicologia da Composição". Uma palavra sem palavra, portanto, mas apenas para melhor chegar à sua essência. Um processo de criação claramente definido por Rui Chafes quando diz que o despojamento

\begin{abstract}
puxa-nos directamente para o centro, directamente para a essência, não existe nada em excesso, ficamos entregues a nós próprios. Esse despojamento é uma aproximação do vazio e é (...) um terreno a partir do qual se cria, se geram as coisas (CHAFES, 2015, p. 54).
\end{abstract}

Esta definição ajuda-nos, ainda, a compreender o desmascara-se enquanto poeta ${ }^{21}$ de que nos fala João Alexandre Barbosa, na medida em que ele significa, na obra cabralina, o processo de esvaziamento tanto do sujeito lírico como o do corpus poético. As falas de Joaquim em Os Três Mal-Amados descrevem esse processo que começa no devorar tanto de qualquer signo identitário como do possível saber/fazer poético, até à desagregação do próprio sujeito lírico ${ }^{22}$. Contudo, nessa explosão ou desagregação da metáfora, seja ela a do amor, a da pedra, a do rio, a da flor ou da própria poesia, cria-se apenas um novo terreno para que ela possa auto gerarse e auto gerar a palavra poética e que opera nos dois

\footnotetext{
${ }^{20}$ Em Psicologia da Composição já se recusara a palavra como meramente figura da linguagem poética para se procurar vê-la como acesso à poesia.

21 João Alexandre Barbosa, diz ser esta a lição mais dura para o poeta: "desmascarar-se enquanto poeta e afirmar-se nos limites nas viabilidades da linguagem." (1972, p. 111).

22 Veja-se a forma como esse processo é descrito: “//Joaquim:/ O amor comeu meu nome, minha identidade, meu retrato. $\mathrm{O}$ amor comeu minha certidão de idade, minha genealogia, meu endereço. $\mathrm{O}$ amor comeu meus cartões de visita. $\mathrm{O}$ amor veio e comeu todos os papéis onde eu escrevera meu nome//" (...) "// O amor roeu minha infância, de dedos sujos de tinta, cabelo caindo nos olhos, botinas nunca engraxadas. $\mathrm{O}$ amor roeu o menino esquivo, sempre nos cantos, e que risca os livros, mordia o lápis, andava na rua chutando pedras. Roeu as conversas, junto à bomba de gasolina do largo, com os primos que tudo sabiam sobre passarinhos, sobre uma mulher, sobre mascas de automóvel.//" (MELO NETO, 2003, p. 59-62).
} 
sentidos: do interior da criação poética para o exterior e do exterior - do universo das outras artes mas também de todo e qualquer universo físico - para o interior da poesia.

Assim, o exercício poético não é apenas uma luta corporal com o texto ${ }^{23}$ - descrita, tal como vimos, em "A Lição de Poesia" - própria ao criador com a criatura/ texto ${ }^{24}$ pois ela continuará a ser travada pelo leitor como forma de aceder ao texto. Como sugere Lobo Antunes, essa exigência necessita de um abandono e de uma vigilância que é traduzida pela metáfora de cegueira atenta, ou seja:

[a] capacidade de receber o que há de aparição no seio da aparência, como dizia o português Teixeira de Pascoaes, para que todo o seu rigoroso e implacável labor nos impregne, entrando nas nossas veias com um rigor quase cruel, numa linguagem aparentemente simples e por vezes, de início, difícil de aceitar porque em absoluto nova (LOBO ANTUNES, 2012, s.p.).

\section{A explosão da flor}

Como veremos, a luta - a do poeta como a do leitor - não cessará de se aprofundar porque dela é possível extrair o princípio inerente a qualquer "/princípio do mundo, [ou] lua nova.//"25 como anuncia "A Lição de Poesia". Com efeito, existe a consciência de que a criação deste mundo novo consistirá num paciente trabalho já possível de antever em Os três Mal-Amados. Aqui se falava de um livro onde se fariam "exercícios" para que "a voz de uma cadeira, de uma cômoda" fosse compreensível e acesso à "lucidez, que, ela só, nos pode dar um modo novo e completo de ver uma flor, de ler um verso." (MELO NETO, 2003, p. 63-64). Embora, nesta fase, a flor emergisse de um universo onde ainda não podia desabrochar ${ }^{26}$, elege-se como elemento importante do trabalho poético que tem por finalidade vê-la, assim como o verso, de uma outra forma.

A experiência à volta da palavra flor feita em "Antiode", onde o sujeito lírico luta para a arrancar à poesia profunda ${ }^{27}$, revela o desejo de a transformar

\footnotetext{
${ }^{23}$ No poema "A Lição de Poesia", o sujeito lírico fala precisamente de uma "/luta branca onde corre o sangue / de suas veias de água salgada//" (MELO NETO, 2003, p. 78).

${ }^{24}$ No sentido que lhe dá o sujeito lírico no poema "A Lição de Poesia" pois nele se fala de naturezas vivas e se compara aquilo que cria a monstros "/ germinados em seu tinteiro.//" (MELO NETO, 2003, p. 78).

25 "A Lição de Poesia", Ibidem.

${ }^{26}$ Diz-se em $O$ Engenheiro: “/Já não podias desenhar/ sequer uma linha; um nome, sequer uma flor/ desabrochava da mesa://" (MELO NETO, 2003, p. 78).

27 O poema "Antiode" de Psicologia da Composição tem como subtítulo ou nota de introdução "Contra a poesia dita profunda".
}

numa máquina ${ }^{28}$ que permita todas as composições. Argumenta-se com intensidade de modo a fazer explodir a metáfora naquela que é dita a "poesia profunda". A tese de que a poesia/flor é "fezes" ou outro qualquer "estrume do poema" é elaborada com base numa argumentação formulada a partir de várias interrogações que conduzem à ideia de que a flor/poesia pode ser mesmo verso inscrito no verso ou palavra impossível de poema. A poesia será "fezes" porque estas são "vivas" também pela leveza da palavra.

Será o trabalho de composição exposto no poema "Alguns Toureiros" de Paisagens com figuras que vai definir claramente um universo onde se desenvolve a escuta para se ver a flor de um modo novo, tal como já fora experimentado em Psicologia da Composição. A palavra flor surge com o esplendor não da sua lírica beleza mas da metáfora da própria poesia. Por essa razão, ela define, mais uma vez, a luta à volta do gesto, do corpo, da matéria ou do susto onde, por fim, o fio frágil da vida ${ }^{29}$ pode surgir. O nome próprio de cada toureiro assinala, desde logo, a particularidade e a complexidade da composição de cada gesto. A flor é a metáfora que delineia a gestualidade de cada um e que se vai desdobrando em graciosidade e precisão, espontaneidade e retenção, angústia e explosão até se tornar, pelo trabalho de Manolo González, dito Manolete, numa apoteose de agudeza e emoção onde se atinge o poema sem perfume e sem poesia : "/ sem perfumar sua flor,/ sem poetizar seu poema.//" (MELO NETO, 2003, p.157-158). A lição de poesia, neste contexto, é a de que a arte de tourear, tal como a flor, não é mero adorno, mas matéria poética com a qual se trabalha. A poesia é a profundidade dessa arte que leva o toureiro a roçar a morte até ao fluido aceiro da vida. É daí que o poeta recebe uma aprendizagem maior para o seu exercício poético. Não são as associações de imagens ligadas à flor que importam, nem o transbordamento subjetivo de sentidos da palavra flor mas antes aquilo que ela é enquanto poesia porque a flor é tanto palavra-gesto como palavra-verso. Aqui se entenderia a importância do acompanhamento do trabalho do outro nesse escutar sensível que implica a capacidade de receber o que há de aparição no seio da aparência, como nos esclarece Teixeira de Pascoes $^{30}$ e que, na arte de tourear, implica a revelação do mistério com que cada um guarda a sua flor. Não só se aprende a ver a flor contida no trabalho concreto do corpo mas a forma como cada um a cultiva e a preserva. Como refere Ana Andresen de Sousa Tavares, nessa intimidade revela-se o mito da originalidade:

\footnotetext{
28 “//...] explosão/ posta a funcionar,/ como uma máquina,/ uma jarra de flores.//" (MELO NETO, 2003, p. 101).

29 Neste poema, utiliza-se a expressão "o fluido aceiro da vida".

30 Já citado neste trabalho por António Lobo Antunes (2012).
} 
O mito da originalidade, enquanto padrão da qualidade, por excelência, obriga a que cada poeta procure realizar sua obra não o que nele é comum a todos os homens, com a vida que nele, na rua, compartilha com todos os homens, mas com o que nele é mais íntimo e pessoal, privado, diverso de todos (TAVARES, 2003, p. 229).

O interesse em revisitar tanto o universo linguístico como o movimento do corpo na sua gestualidade e na sua poesia, seja ela para tourear, pintar, cantar, escrever, pode conduzir o sujeito lírico até ao seu próprio universo paisagístico. Nesse andamento com o outro - até porque a poesia se faz andando ${ }^{31}$-, trabalha-se para que a paisagem seja dita de outra forma. Para tal, João Cabral de Melo Neto é fiel a outros procedimentos que estão por detrás da sua criação poética como o impulso que se vai buscar num corpus textual existente para o renovar. É nesse sentido que João Cabral fala de leitura e análise da literatura de cordel, da literatura popular nordestina onde vai buscar a tensão do verso que transpôs, por exemplo, em Morte e Vida Severina ${ }^{32}$. É precisamente neste texto que descreve a caminhada de um retirante, que desce até ao litoral em busca de melhor vida mas que apenas acaba por roçar "o fio frágil da vida". Esta mesma expressão surge relacionada com a arte de tourear no poema "Diálogo": "// Como à procura do nada/ é a luta também vazia/ entre o touro,/ vazia, embora precisa,// em que se busca afiar/ em terrível parceria/ no fio agudo de facas/ o fio frágil da vida.//" (MELO NETO, 2003, p. 163). A luta que cada um leva a cabo serve para se aproximar dessa busca vazia, porque destituída de qualquer dimensão abstracta ou transcendente, mas que apenas revela a arte da vida. Este será, provavelmente, o fim último de tudo ou de qualquer caminhada, seja ela através da escrita, da paisagem ou da própria vida: regressar às suas águas salgadas e à sua flor. Em ambos os casos, o poeta aprende tanto com a caminhada do retirante ou a do rio, como com a do toureiro em direção a esse fio frágil.

Tudo estava já dito à partida e a escrita do poeta - talvez metáfora dessas caminhadas ou dessas artes da vida - também chega ao deserto, ao vazio, à linha geométrica da paisagem inaugural que é o Nordeste e, particularmente, Pernambuco. Volta-se assim ao silêncio, à palavra antes de ser palavra e nela se clama por uma paisagem inaugural: "Impossível de apagar as imagens de um vazio 'onde só a pedra é que ficava': o domínio mineral de uma topografia ostensivamente cheia de nada." (SECCHIN, 2014, p. 390).

\footnotetext{
${ }^{31}$ Logo nos primeiros textos de João Cabral de Melo Neto, em Pedra de Sono ( 1940-1941) surge esta ideia num poema intitulado "A poesia Andando".

${ }^{32}$ Como explica em entrevista a António Carlos Secchin (1985, p. 304).
}

Haverá, então, uma só travessia? Ou, dito de outra forma, será esta travessia pela paisagem da poesia e pela poesia da paisagem a unidade da sua flor? Poderá ela ser procurada numa possível unidade que só a poesia poderia conter? Não se abandona a raiz da poesia porque daí se extrai a sua pureza e a sua unidade, mas é numa escrita, como nos diz Maria Zambrano, oposta, como temos vindo a ver, ao romantismo, que se pode ir buscar a profundidade das coisas:

\begin{abstract}
La 'poésie pure', du bord opposé au romantisme mais avec plus de profondeur et à bon droit plus encore, pourrions-nous dire, a fondé l'idée que la poésie est tout. Tout, entendons-nous, par rapport à la metaphysique; tout, quant à la connaissance, tout quant à la réalisation essentielle de l'homme. Il suffit au poète de faire de la poésie pour exister; c'est la forme la plus plus pure de réalisation de l'essence humaine. (ZAMBRANO, 2003 [1939], p. 115).
\end{abstract}

Será o trabalho de clareza e de contenção que lhe pode mostrar a poesia ${ }^{33}$ e com ela traçar um caminho para chegar à paisagem inaugural. Esta mesma travessia adivinha-se, assim, no "/fazer o que sabia/como se o aprendesse ainda./" $" 34$ e é por isso que ela é metáfora da interrogação que permanece viva a cada passo: ela encontra-se na caminhada do retirante, na gestualidade do toureiro, no canto da Andaluzia ${ }^{35}$ porque poderá ser explosão da vida ${ }^{36}$. Deste modo, esta poesia, antes de ser texto, já era matéria: maçã, lama, flor, pedra, rio...

Regressamos ao pensamento de Ortega y Gasset para tecer algumas conclusões. Diz este autor: "Nada hay tan lícito como empequeñecer el mundo por medio de nuestras manías y cegueras, disminuir la realidad, suprimir imaginariamente pedazos do lo que es." (ORTEGA y GASSET, 1932, p. 22). A poesia de João Cabral de Melo Neto, através da sua procura de clareza e concisão, procura dar a ver estes pedaços de que é também feita a realidade e que o homem tende a suprimir ou, muito simplesmente, a não ver. Deste modo, ela vem-nos mostrar não a experiência do mundo de um homem sem alma ${ }^{37}$, como chegou a ser designado, mas que a força anímica talvez esteja na profundidade das coisas mais que não seja na sua relação que com elas tece o mundo/os mundos criado/criados pelo

\footnotetext{
${ }^{33}$ Se em "A Lição de Poesia", "/diante da folha em branco/" o sujeito lírico falava da possibilidade de um "/ princípio do mundo (...)/", em Psicologia da Composição já é possível atingir-se a pureza procurada: "/ Eu me refugiu nesta poesia pura.".

${ }^{34}$ No poema "O Sim Contra o Sim" de Serial, na parte que dedica ao trabalho de Mondrian.

${ }^{35}$ No poema "Diálogo" de Paisagens com Figuras.

${ }^{36}$ Tal como é enunciado nos últimos versos de Morte e Vida Severina. (NETO, 2003, p. 202).

37 Veja-se o título do livro de José Castello: João Cabral de Melo Neto - O homem sem alma (CASTELLO, 1996).
} 
homem ${ }^{38}$. Por outras palavras, a materialidade e a realidade destas coisas resultam de um movimento que vem revelar a explosão da vida. Veja-se, a este propósito, a maneira como cada oferenda ao Menino em Morte e Vida Severina, é animada pelas inúmeras possibilidades e formas de ser vista e utilizada. O despojo não é uma maneira redutora de ver o mundo mas apenas outra maneira de o ver. Na desconstrução de qualquer dimensão da matéria, nessa procura do vazio ou do nada, parecer estar sempre a construção de qualquer outra coisa, ou pelo menos da sua procura. Deste modo, não é do lírico ou dos objetos metafísicos que a poesia de João Cabral de Melo Neto foge para se aproximar da explosão da flor como metáfora também de explosão da vida, como em Morte e Vida Severina ${ }^{39}$-, mas sim aproximar-se desses tantos outros modos de ver que compõem o mundo. $\mathrm{O}$ movimento de afastamento e aproximação faz-se a partir de um exercício paciente e útil que consiste em aproximar essas duas pontas - "/(flor, imagem de// duas pontas, como uma corda).[...] $]^{/ 440}$ - que formam esse fio frágil entre a vida e a morte e do qual a poesia se aproxima.

\section{Referências}

ALMINO, João. "O domador de sonhos" e outras imagens da pedra - A construção da poética de João Cabral de Melo Neto de "Pedra de Sono" a "Educação pela Pedra". In: Colóquio de Letras, n. 157/158, p. 127-158, jul. 2000.

ATHAYDE, Félix. Ideias Fixas de João Cabral de Melo Neto. Rio de Janeiro: Nova Fronteira, 1998.

BARBOSA, João Alexandre. Linguagem e Metalinguagem na poesia de João Cabral de Melo Neto. Revista do Instituto de Estudos Brasileiros, São Paulo, n. 11, p.93-111, apr. 1972. Disponível em: <http:/www.revistas.usp.br/rieb/article/view/ 69736/72395>. Acesso em: 02 mar. 2017. http://dx.doi. org/10.11606/issn.2316-901X.v0i11p93-111

CASTELLO, José. João Cabral de Melo Neto - O homem sem alma. Rio de Janeiro: Rocco, 1996.
CHAFES, Rui. Sob a pele - Conversas com Sara Antónia Matos. Lisboa: Documenta, 2015.

LOBO ANTUNES, António. Prefácio a $O$ rio/João Cabral de Melo Neto. Rio de Janeiro: Objetiva, 2012.

MELO NETO, João Cabral. Obra Completa. Rio de janeiro: Editora Nova Aguilar, 2003.

NUNES, Maria Leonor. Carlos Vidal - Libertar a pintura do visível. In Jornal de Letras, n. 1181, p. 20-22, jan. 2016.

ORTEGA Y GASSET, José. Obras de José Ortega y Gasset. Madrid: Espasa-Calpe, 1932.

SARAIVA, Arnaldo. Dar a ver e a se ver no extremo - O poeta e a poesia de João Cabral de Melo Neto. Porto: Afrontamento, 2014.

SECCHIN, António Carlos. João Cabral: A Poesia do Menos. São Paulo: Duas Cidades, Brasília: I.N.L. e F.N. Pró-Memória, 1985.

SECCHIN, António Carlos. João Cabral: uma fala só lâmina. São Paulo: Cosac Naify, 2014.

SENNA, Marta de. João Cabral - Tempo e Memória. Rio de Janeiro: Antares, 1980

SÜSSEKIND, Flora (Org.). Correspôndência de Cabral, com Bandeira e Drummond. Rio de Janeiro: Nova Fronteira, 2001.

TAVARES, Maria Andersen de Sousa. Poesia e Pensamento - Wallace Stevens, Francis Ponge, João Cabral de Melo Neto. Lisboa: Caminho, 2001.

TAVARES, Gonçalo M. Atlas do corpo e da imaginação Teoria, fragmentos e Imagens. Lisboa: Caminho, 2013.

ZAMBRAno, M. Philosophie et Poésie. Paris: José Corti, 2003 [1939].

Autora:

GLÓRIA ALHINHO

Université Bordeaux Montaigne. Pessac, França.

gloriaalhinho@gmail.com

Recebido: 30/05/2018

Aprovado: 30/05/2018

\footnotetext{
38 É um motivo recorrente na poesia de João Cabral de Melo Neto a forma como a paisagem e o homem se contagiam (TAVARES, 2001, p. 300) e, poderíamos acrescentar, a forma como o homem e as coisas se interpenetram.

39 Os últimos versos de Morte e Vida Severina: “/ E não há melhor resposta/ que o espetáculo da vida:/ vê-la desfiar seu fio,/ que também se chama vida,/ ver a fábrica que ela mesma,/ teimosamente, se fabrica,/ vê-la brotar como há pouco/ em nova vida explodida; mesmo quando é assim pequena/a explosão, como a ocorrida;/mesmo quando é uma explosão/ como a de há pouco, franzina;/mesmo quando é a explosão/de uma vida severina.//" (MELO NETO, 2003, p. 202).

40 Do poema "Antiode" de Psicologia da Composição (idem, p. 99).
} 